\title{
Hydrochemical evaluation of groundwater quality of the Tista floodplain, Rangpur, Bangladesh
}

\author{
Sudip Saha ${ }^{1}$ A. H. M. Selim Reza ${ }^{1}$ Mrinal Kanti Roy ${ }^{1}$
}

Received: 24 March 2017 / Accepted: 15 October 2019 / Published online: 29 October 2019

(c) The Author(s) 2019

\begin{abstract}
The Tista is a Trans-Himalayan river that flows through Sikkim and West Bengal states of India and Rangpur division of Bangladesh and finally falls into the Brahmaputra River. The presence of numerous abandoned channels with various degrees of aggradations indicates large migrations of the Tista River. The $\mathrm{pH}$ value of groundwater varies from 6.20 to 7.40 which indicate the slightly alkaline to acidic nature of the studied aquifers. The mean abundance of major cations is $\mathrm{Na}^{+}>\mathrm{Ca}^{+2}>\mathrm{Mg}^{+2}>\mathrm{K}^{+}$, whereas the major anions is $\mathrm{HCO}_{3}{ }^{-}>\mathrm{Cl}^{-}>\mathrm{SO}_{4}^{-2}$. Among the cations, $\mathrm{Na}^{+}$is the dominant and $\mathrm{K}^{+}$is the lowest constituents, whereas $\mathrm{HCO}_{3}^{-}$is most abundant and $\mathrm{SO}_{4}^{-2}$ is the minor constituents in anions. The hydrochemical facies of groundwater show that sodium, sodium-magnesium, sodium-calcium, sodium-magnesium-calcium and sodium-calcium-magnesium are cation facies and chloride-bicarbonate, bicarbonate-chloride and bicarbonate are anion facies. Correlating with WHO (Guidelines for drinking-water quality, 1, World Health Organisation, Geneva, 1997) and EQS (Environmental quality standard, Department of Environment, Bangladesh, 1989) guideline values for drinking water and public health, it may be concluded that the groundwater of the study area is suitable for all drinking and domestic purposes, where only three samples exceed the maximum allowable limit of potassium. Based on total hardness, SAR, RSC, PI, SSP and $\mathrm{MH}$ values, it can be summarized that the groundwater of the investigated area is suitable for irrigation purpose. On the basis of Australian and UNESCO standard, the groundwater of the study area is also suitable for livestock purposes. The Rangpur area is hydrogeologically active by the processes like ion exchange and dissolution. $\mathrm{Ca}^{2+}, \mathrm{Mg}^{2+}$ and $\mathrm{HCO}_{3}{ }^{-}$are produced by the dissolution of limestone and dolomite.
\end{abstract}

Keywords Hydrochemical facies $\cdot$ Groundwater $\cdot$ Total hardness $\cdot$ Rangpur $\cdot \mathrm{pH}$

\section{Introduction}

Water is an important natural resource, which forms the core of ecological system (Selvam et al. 2013). The demand of groundwater increases with some factors like increasing population and pollution of surface water bodies by agriculture and industrialization. The study area, Rangpur, lies in north western part of Bangladesh. The area lacks industries and is dominated by agricultural activities. The water is mainly used here for drinking, domestic, irrigation and industrial purposes. Hydrochemical study is a useful tool to identify the suitability of groundwater. Both the physical and chemical parameters are taken into considerations. The

Sudip Saha

sudips_geologist@yahoo.com

1 Department of Geology and Mining, University of Rajshahi, Rajshahi 6205, Bangladesh chemical parameters taken into consideration are hydrogen ion concentration $(\mathrm{pH})$, specific electrical conductance (EC), total dissolved solids (TDS) and all major cations and anions. Several researchers had carried out extensive studies on water quality of the Tista floodplain. Islam et al. (2017) studied the trace element contents of Rangpur district and concluded that the trace element quality of groundwater is mainly related to natural/geogenic sources followed by anthropogenic sources. Salinity with increasing depth has been reported in lower Tista floodplain which is an indicative of mixing of fresh and saline bodies due to marine transgression during Holocene period in the Bengal delta (Afroza et al. 2009). The present research work shows that the quality of the groundwater is mainly controlled by geogenic processes to a lesser extent by anthropogenic activities.

Groundwater is the principal source of water supply for irrigation, drinking and domestic purpose. Higher concentrations of chemical constituents negatively affect the 
environment and public health (Anderson 2014). Examples of groundwater pollution sources include salt water intrusion, leakage of fertilizer, natural erosions and other anthropogenic activities. The present study is conducted to assess the groundwater quality for understanding its suitability for various purposes. The study will also reveal the sources of chemical constituents of groundwater.

The main objective of this research work is to assess the groundwater quality for drinking, domestic and irrigation purposes and to characterize the hydrogeochemical processes which are dominant in the study area.

\section{Study area}

The Tista River originated from the Pauhunri (Teesta Kangse) glacier above $7068 \mathrm{~m}$ and flows southwards through gorges and rapids in the Sikkim Himalaya (Meetei et al. 2007; Wiejaczka et al. 2014). Overall drainage pattern of the Tista River is anastomosing and braided type (Bhattacharyya and Mukherjee 2009). The presence of numerous abandoned channels with various degrees of aggradations indicates largescale migrations of the rivers. The Tista is a Trans-Himalayan River that flows through the granites and volcanic rocks of Neogene and Paleogene age (i.e., about 2.6 to 65 million years old). The aquifers of the Tista fan, both active fan and inactive, that lie in Rangpur and Dinajpur districts are composed of coarser sediments and have the highest transmissivity in Bangladesh varying from 1000 to $7000 \mathrm{~m}^{2} /$ day (UNDP 1982; Hussain and Abdullah 2001). The aquifers mainly composed the piedmont deposits of old Tista floodplain containing fine, medium and coarse sands with a higher proportion of silt and clay with mean thickness of $2 \mathrm{~m}$. In some places, clay lenses are found in the sands. The thickness of the aquifer varies from 5 to $50 \mathrm{~m}$ with average thickness of $20 \mathrm{~m}$ (Hussain and Abdullah 2001). The aquifer of the study area is mainly extensive unconfined and locally semi-confined in Kurigram district. The temperature of Rangpur varies from 32 to $11^{\circ} \mathrm{C}$, and the annual average rainfall is $2931 \mathrm{~mm}$ (Fig. 1).

\section{Methodology}

Nineteen groundwater samples were collected from tubewell of shallow aquifers in July 2014 in order to study physicochemical characters of the study water. The $\mathrm{pH}$ and electrical conductance (EC) of groundwater samples were measured in the field using $\mathrm{pH}$ meter (HANNA) and EC meter (HANNA), respectively. The temperature of the groundwater was measured and recorded in situ. Sampling was carried out using pre-cleaned polythene bottles, after pumping continuously 10-15 min until the temperature, electrical conductivity (EC) and $\mathrm{pH}$ reading had stabilized. To analyze the water chemistry, $100 \mathrm{~mL}$ polythene two sample bottles were filled at each tubewell. The sampled water was filtered through $0.45 \mu \mathrm{m}$ filters at the time of sampling in order to remove colloidal and suspended materials. Ten drops of ultrapure nitric acid $\left(\mathrm{HNO}_{3}\right)$ was added in one of the bottles to preserve the groundwater for the analysis of cations. Collected samples were preserved at $4{ }^{\circ} \mathrm{C}$ and taken into the laboratory for chemical analyses. $\mathrm{Ca}$ and $\mathrm{Mg}$ were determined by Atomic Absorption Spectrometer, model Shimadzu AA 7000 at 422.7 and $285.2 \mathrm{~nm}$ wavelength. A flame photometer was used to determine the concentration of $\mathrm{Na}$ and $\mathrm{K}$ at 589 and $765.5 \mathrm{~nm}$ (Afroza et al. 2009). Chloride $\left(\mathrm{Cl}^{-}\right)$was determined by argentometric method using standard $\mathrm{AgNO}_{3}$ solution as titrate and potassium chromate as indicator (APHA 1995). Carbonate $\left(\mathrm{CO}_{3}{ }^{2-}\right)$ and bicarbonate $\left(\mathrm{HCO}_{3}{ }^{-}\right)$were determined with titration with $\mathrm{HCl} . \mathrm{SO}_{4}$ was determined by $\mathrm{UV}$-visible spectrophotometer, model Shimadzu UV-1800 at a wavelength of $535 \mathrm{~nm}$. Based on the results of the physicochemical analyses, irrigation quality parameters like total hardness (TH), sodium absorption ratio (SAR), residual sodium carbonate (RSC), permeability index (PI), soluble sodium percentage (SSP) and magnesium hazard were calculated.

Total hardness (TH) of the water samples was calculated by using the formula as given by Raghunath (1987) and Sawyer et al. (2003):

$\mathrm{TH}$ in $\mathrm{mg} / \mathrm{L}=\left(\mathrm{Ca}^{+}+\mathrm{Mg}^{+}\right) \times 50$

where all the concentrations are in $\mathrm{meq} / \mathrm{L}$.

Residual sodium carbonate (RSC) of the water was estimated by the formula (Eaton 1950; Raghunath 1987):

$\mathrm{RSC}=\left(\mathrm{CO}_{3}^{2-}+\mathrm{HCO}_{3}^{-}\right)-\left(\mathrm{Ca}^{+}+\mathrm{Mg}^{+}\right)$

where all the concentrations are in $\mathrm{meq} / \mathrm{L}$.

Permeability index (PI) was computed using equation developed Doneen (1964) and Raghunath (1987):

$\mathrm{PI}=\frac{\mathrm{Na}+\sqrt{\mathrm{HCO}_{3}}}{\mathrm{Ca}+\mathrm{Mg}+\mathrm{Na}} \times 100$

where all the concentrations are in $\mathrm{meq} / \mathrm{L}$.

The sodium adsorption ratio was estimated by using the formula formulated by Richards (1954):

$\mathrm{SAR}=\frac{\mathrm{Na}}{\sqrt{\mathrm{Ca}+\mathrm{Mg}} / 2}$

where all the concentrations are in $\mathrm{meq} / \mathrm{L}$.

Soluble sodium percentage (SSP) of water was computed using the equation given by Todd (1980):

$\mathrm{SSP}=\frac{(\mathrm{Na}+\mathrm{K}) \times 100}{(\mathrm{Ca}+\mathrm{Na}+\mathrm{Mg}+\mathrm{K})}$

where all the concentrations are expressed in meq/L. 


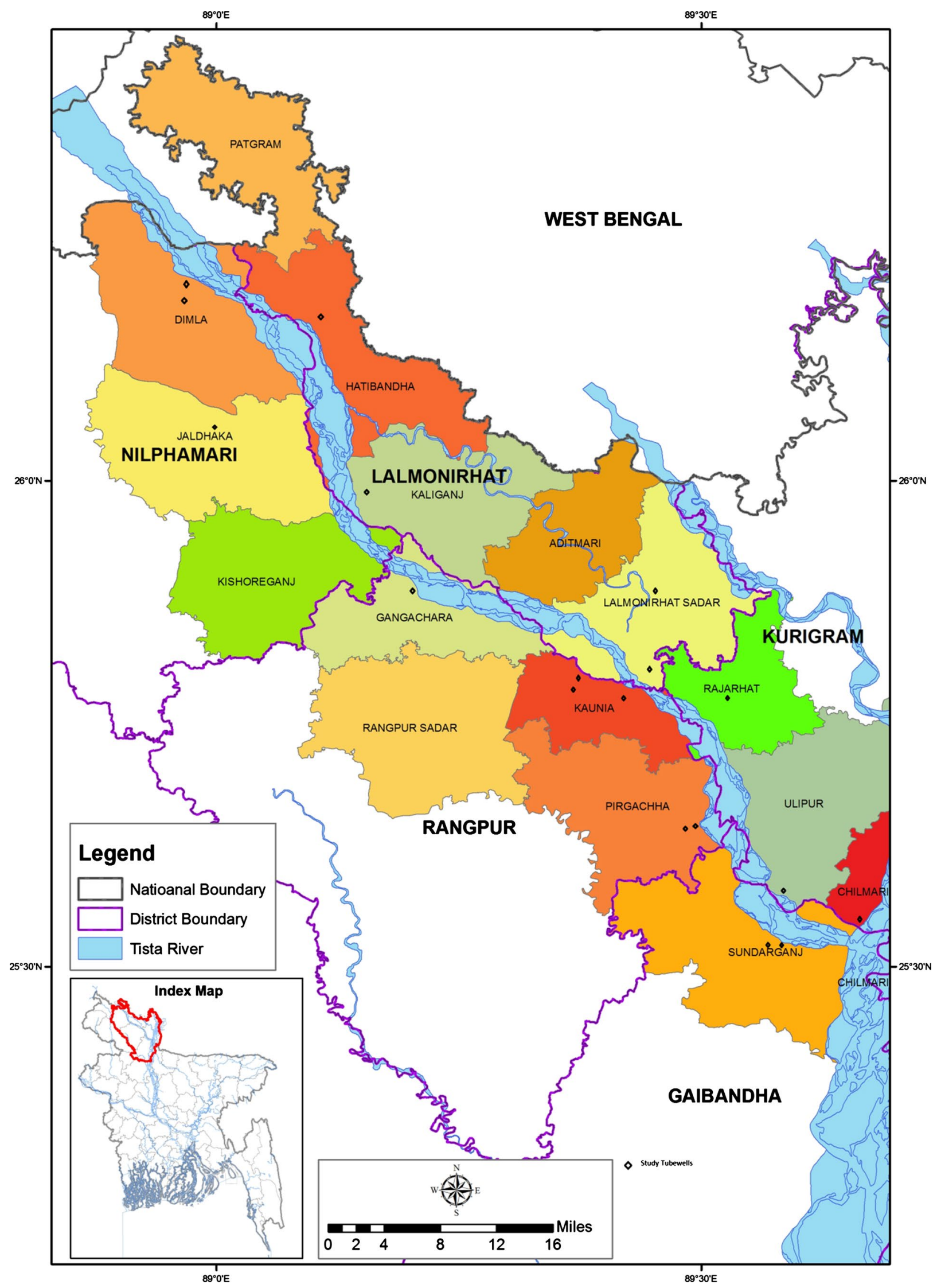

Fig. 1 Map of the study area 
Magnesium hazard (MH) was calculated by following the equation developed by Szabolcs and Darab (1964) for irrigation use of water:

$\mathrm{MH}=\frac{\mathrm{Mg} \times 100}{\mathrm{Mg}+\mathrm{Ca}}$

where all the concentrations are expressed in meq/L.

\section{Results and discussion}

\section{On-site field measurements}

$p H$ The $\mathrm{pH}$ values of the studied samples are shown in Table 1, where minimum is 6.20 , maximum is 7.40 , which is almost permissible ranging 6.5-8.5 of WHO (1997) and median value is 6.50 . The $\mathrm{pH}$ values of the groundwater varying from 6.20 to 7.40 are an indicative that the groundwater aquifer conditions vary from slightly acidic to slightly alkaline. $\mathrm{Low} \mathrm{pH}(\mathrm{pH}>7)$ groundwaters are resulted from the absence of calcite or nearly so, and the main host rock is granitic origin (Robins 2002). The $\mathrm{pH}$ of natural water is an important factor which is influenced by the chemical and biological parameters of the water as well as toxicity of many compounds (Haque 2009).

Temperature The temperature of the investigated groundwater was uniform, which varied with a range from 25 to $28{ }^{\circ} \mathrm{C}$ and the median value is $26^{\circ} \mathrm{C}$ as shown in Table 1 .

$E C$ The $\mathrm{EC}$ values of groundwater samples range from 110 to $1190 \mu \mathrm{S} / \mathrm{cm}$. Based on the EC, the groundwater of the study area is fresh in nature $(<1000 \mu \mathrm{S} / \mathrm{cm})$ and only one sample is slightly saline $(>1000 \mu \mathrm{S} / \mathrm{cm})$.

\section{Hydrogeochemistry}

\section{Major cations and anions}

The mean abundance of major cations is $\mathrm{Na}^{+}>\mathrm{Ca}^{+2}>\mathrm{Mg}^{+2}>\mathrm{K}^{+}$, whereas the major anions is $\mathrm{HCO}_{3}{ }^{-}>\mathrm{Cl}^{-}>\mathrm{SO}_{4}^{-2}$. Among the cations, $\mathrm{Na}^{+}$is the dominant and $\mathrm{K}^{+}$is the lowest constituents, whereas $\mathrm{HCO}_{3}{ }^{-}$is most abundant and $\mathrm{SO}_{4}^{-2}$ is the minor constituents in anions.

Sodium $\left(\mathrm{Na}^{+}\right)$Sodium $\left(\mathrm{Na}^{+}\right)$is the most abundant member of the alkali metal group of studied groundwater. Sodium concentration of groundwater of the Tista River Basin varies from 11.5 to $80.5 \mathrm{mg} / \mathrm{L}$. The maximum concentration of sodium is $80.5 \mathrm{mg} / \mathrm{L}$, reported in Kaunia Upazila of Rangpur and Sundarganj of Gaibandha. None of the samples exceeds the maximum permissible limits of sodium of recommended standards of WHO (1997) and EQS (1989).

Tista floodplain sediments contain feldspar at different locations (Mazumder et al. 1994). The results suggest that sodium in groundwater was derived from the weathering of halite and silicate minerals like feldspar in this area (Khan et al. 2014; Mostafa et al. 2017). The agricultural by-products might be the other sources of sodium content of the groundwater in the study area (Hem 1989; Sultana 2009).

Potassium $\left(\mathrm{K}^{+}\right)$Potassium $\left(\mathrm{K}^{+}\right)$is the second abundant alkali metal reported in the groundwater samples of the investigated area. The concentrations of potassium $\left(\mathrm{K}^{+}\right)$ are lower than that of sodium because of slower weathering rate of potassium bearing rocks than those of sodium bearing rocks. Potassium is resulted from the chemical decomposition of the sylvite $(\mathrm{KCl})$ and silicates especially clay minerals. Potassium can be added to groundwater through fertilizer use and breakdown of animal or waste products.

The average concentration of potassium $\left(\mathrm{K}^{+}\right)$in the study is $6.51 \mathrm{mg} / \mathrm{L}$, whereas maximum content of $\mathrm{K}^{+}$is $23.4 \mathrm{mg} / \mathrm{L}$ at Tista, Lalmonirhat and minimum concentration is $0.78 \mathrm{mg} / \mathrm{L}$ at Stadium Para, Lalmonirhat. Three groundwater samples exceed the maximum permissible limit of potassium of recommended standards of WHO (1997) and EQS (1989).

Calcium $\left(\mathrm{Ca}^{2+}\right)$ The maximum concentration of calcium $\left(\mathrm{Ca}^{2+}\right)$ is $36 \mathrm{mg} / \mathrm{L}$, minimum calcium content is $4 \mathrm{mg} / \mathrm{L}$, and the median value for concentration of calcium is $8 \mathrm{mg} / \mathrm{L}$. Calcium is the most abundant alkaline earth in the groundwater of the aquifer of the Tista River Basin. All of the groundwater samples were within the permissible limit for WHO (1997) and EQS (1989).

The normal concentration of calcium in groundwater ranges from 10 to $100 \mathrm{mg} / \mathrm{L}$ ( $\mathrm{Nag}$ 2009). The basic sources of calcium are carbonate rocks, i.e., limestones and dolomites, which are dissolved by carbonic acid in groundwater. The chemical breakdown of calcic-plagioclase feldspars and pyroxenes may be responsible for calcium in the groundwater (Ganyaglo et al. 2010). Calcium can also originate as lime in agricultural fertilizers.

Magnesium $\left(\mathrm{Mg}^{2+}\right)$ Magnesium in groundwater derived from the decomposition of dolomite, ferromagnesian minerals like olivine, pyroxene, amphiboles and dark colored micas. In the metamorphic rocks, magnesium occurs in the structure of chlorite, montmorillonite and serpentine (Nag 2009). The reaction involving solution of magnesium is influenced by the amount of $\mathrm{CO}_{2}$ in the groundwater in dissolved condition.

The maximum amount of magnesium is found in the groundwater of Tista, Lalmonirhat $17.01 \mathrm{mg} / \mathrm{L}$, and the minimum concentration is reported in the groundwater of three wells of Rangpur whose values are $2.43 \mathrm{mg} / \mathrm{L}$. The median value of magnesium is $7.29 \mathrm{mg} / \mathrm{L}$. The magnesium content of the all groundwater sample is below the maximum permissible limit of WHO 1997 and EQS 1989. 


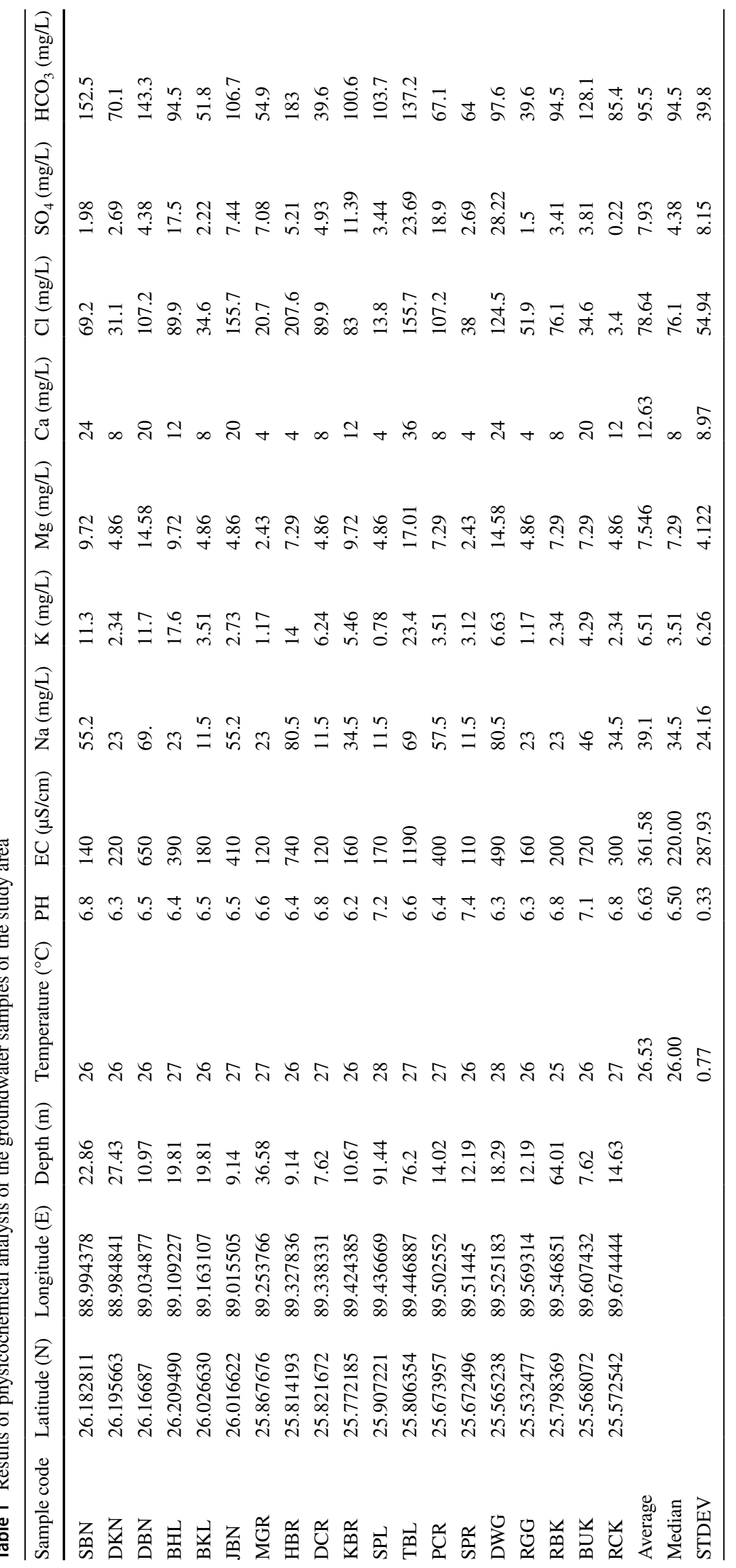




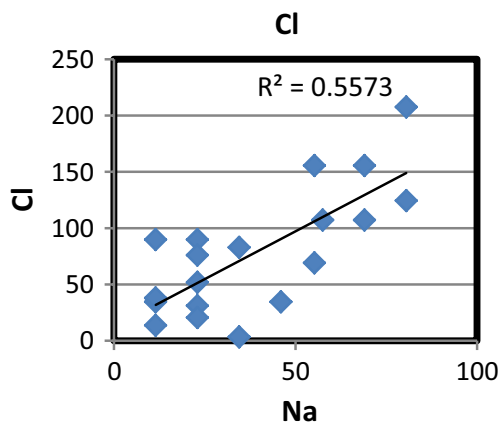

Fig. 2 Correlation of $\mathrm{Na}$ versus $\mathrm{Cl}$

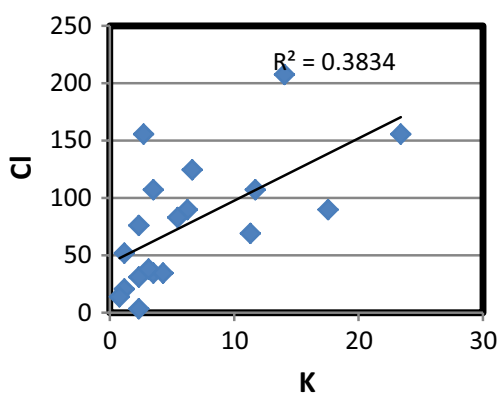

Fig. 3 Correlation of $K$ versus $\mathrm{Cl}$

Chloride $\left(\mathrm{Cl}^{-}\right)$The chloride $\left(\mathrm{Cl}^{-}\right)$concentration of groundwater may be attributed to the presence of chlorides from rocks, evaporates, seawater intrusion, connate and juvenile water, or contamination by industrial waste or domestic sewage. Normally, the concentration of chloride in groundwater is less than $30 \mathrm{mg} / \mathrm{L}$, but concentration of $1000 \mathrm{mg} / \mathrm{L}$ or more is common in arid regions (Nag 2009).

The mean concentration of chloride in the groundwater of present study is $78.64 \mathrm{mg} / \mathrm{L}$. The chloride contents of groundwater of the aquifer of the Tista floodplain range from 3.40 to $207.60 \mathrm{mg} / \mathrm{L}$. The low value of chloride ions is an indication of low salinity of the groundwater of the study area. The chloride content of the all groundwater sample is below the maximum permissible limit of WHO (1997) and EQS (1989). The high concentration of chloride is found in the wells of Nilphamari, Lalmonirhat and Rangpur districts that could be resulted from the mixing of fresh water with seawater. Positive correlation of chloride with sodium and potassium indicates that the principal source of chloride is from halite and sylvite (Figs. 2 and 3).

Sulfate $\left(\mathrm{SO}_{4}^{2-}\right)$ The occurrence of sulfate in groundwater resulted from the oxidation of sulfur of the igneous rocks, the dissolution of the other sulfur bearing minerals. Sedimentary rocks, such as organic shale, may play a key role in this connection by the oxidation of marcasite and pyrite (Matthess 1982; Rahman et al. 2013a, b). The sulfate $\left(\mathrm{SO}_{4}{ }^{2-}\right)$ of the groundwater from the aquifers of the active Tista floodplain varies from 0.22 to $28.22 \mathrm{mg} / \mathrm{L}$. The sulfate content of the all groundwater sample is below the maximum permissible limit of WHO (1997) and EQS (1989). The median value of sulfate $\left(\mathrm{SO}_{4}{ }^{2-}\right)$ content of the groundwater of the study area is $4.38 \mathrm{mg} / \mathrm{L}$. The low concentrations of sulfate suggest that bacterial sulfate reduction has occurred (Kirk et al. 2004). The lower sulfate content of groundwater indicates that the study area lacks industries as the high sulfate contents indicate anthropogenic sources and industrial process (Mostafa et al. 2017).

Bicarbonate $\left(\mathrm{HCO}_{3}^{-}\right)$The possible sources of bicarbonate include the presence of organic matter in the aquifer that is oxidized to produce carbon dioxide, which promotes dissolution of minerals (Khashogji and El Maghraby 2013). The fossil carbon of the calcite and dolomite in the aquifer would contribute half of the bicarbonate ions. This weathering enriches the groundwater in calcium, magnesium and bicarbonate ions. Bicarbonate ions may be resulted from the weathering of silicate minerals (Gastmans et al. 2010).

The concentrations of bicarbonate in the groundwater samples range from 39.6 to $183 \mathrm{mg} / \mathrm{L}$. The concentration of bicarbonate ions is higher in the northern and central portions of the study area, while the bicarbonate content of groundwater decreases with increase in longitude.

\section{Assessment of water quality for drinking}

To evaluate the quality for drinking water and public health quality, the physical and chemical parameters of the groundwater were compared with the prescribed pattern recommended by the World Health Organization (WHO 1997) and Environmental Quality Standard for Bangladesh Table 2. From this correlation Table 2, it can be summarized that $\mathrm{pH}$, TDS, $\mathrm{Na}^{+}, \mathrm{Ca}^{2+}, \mathrm{Mg}^{2+}, \mathrm{Cl}^{-}, \mathrm{SO}_{4}{ }^{2-}, \mathrm{HCO}_{3}{ }^{-}$and $\mathrm{CO}_{3}{ }^{2-}$ values of water from the study area belong to standard limit which can be used for drinking purpose and public health without any risk. Three of the groundwater samples show high $\mathrm{K}^{+}$ concentrations. As much as $16 \%$ of the groundwater samples exceed the maximum allowable limit of the allowable limit for drinking purpose and public health (WHO 1997; EQS 1989).

Correlation coefficient matrix ( $r$ ) The coefficient correlation matrix $(r)$ is one of the important tests that shows the connections between two independent parameters of the water. The most familiar measure of dependence between two parameters of water is the Pearson product moment correlation coefficient matrix. It is a measure to demonstrate how well one variable predicts the other (Bahar and Reza 2010; Howlader et al. 2014). The correlation coefficient, $r$, ranges from -1 to +1 . When the value of $r$ is close to -1 , the relationship is demarcated as anti-correlated or has a negative slope. The association is considered to be correlated or have a positive slope, 
Table 2 Correlation between the groundwater samples of the study area with the standard limits prescribed by WHO (1997) and EQS (1989) for drinking water purposes

\begin{tabular}{|c|c|c|c|c|c|c|c|c|}
\hline \multirow[t]{2}{*}{ Parameter } & \multirow[t]{2}{*}{ Unit } & \multirow{2}{*}{$\begin{array}{l}\text { WHO drinking water } \\
\text { standard WHO (1997) } \\
\text { Min.-Max. }\end{array}$} & \multirow{2}{*}{$\begin{array}{l}\text { EQS drinking } \\
\text { water EQS (1989) } \\
\text { Min.-Max. }\end{array}$} & \multicolumn{4}{|c|}{ Groundwater in the study area } & \multirow{2}{*}{$\begin{array}{l}\text { Number of samples } \\
\text { above acceptable } \\
\text { limit }\end{array}$} \\
\hline & & & & Min.-Max. & Average & Median & Std. dev. & \\
\hline $\mathrm{pH}$ & - & $6.5-8.5$ & $6.5-8.5$ & $6.20-7.40$ & 6.63 & 6.50 & 0.33 & None \\
\hline EC & $\mu \mathrm{S} / \mathrm{cm}$ & - & - & $110-1190$ & 361.58 & 220.00 & 287.93 & - \\
\hline TDS & $\mathrm{mg} / \mathrm{L}$ & $500-1500$ & $500-1500$ & $73.70-797.30$ & 242.25 & 147.4 & 192.91 & None \\
\hline $\mathrm{Na}^{+}$ & $\mathrm{mg} / \mathrm{L}$ & 200 & 200 & $11.5-80.5$ & 39.1 & 34.5 & 24.16 & None \\
\hline $\mathrm{K}^{+}$ & $\mathrm{mg} / \mathrm{L}$ & 12 & 12 & $0.78-23.8$ & 6.51 & 3.51 & 6.26 & 3 Samples \\
\hline $\mathrm{Mg}^{2+}$ & $\mathrm{mg} / \mathrm{L}$ & $50-150$ & $30-50$ & $2.43-17.01$ & 7.546 & 7.29 & 4.122 & None \\
\hline $\mathrm{Ca}^{2+}$ & $\mathrm{mg} / \mathrm{l}$ & $75-200$ & - & $4.0-36.0$ & 12.63 & 8 & 8.97 & None \\
\hline $\mathrm{Cl}^{-}$ & $\mathrm{mg} / \mathrm{l}$ & $200-600$ & $150-600$ & $3.40-207.60$ & 78.64 & 76.1 & 54.94 & None \\
\hline $\mathrm{SO}_{4}^{2-}$ & $\mathrm{mg} / \mathrm{l}$ & $200-400$ & 400 & $0.22-28.22$ & 7.93 & 4.38 & 8.15 & None \\
\hline $\mathrm{HCO}_{3}^{-}$ & $\mathrm{mg} / \mathrm{l}$ & - & - & $39.6-183.0$ & 95.5 & 94.5 & 39.8 & - \\
\hline $\mathrm{CO}_{3}{ }^{2-}$ & $\mathrm{mg} / \mathrm{l}$ & 45 & - & 0 & 0 & 0 & 0 & None \\
\hline
\end{tabular}

while the value of $r$ is close to +1 . If the value of $r$ tends to be zero, the points are considered to become less correlated and eventually are uncorrelated (Srivastava and Ramanathan 2008; Howlader et al. 2014).

The correlation matrices for physicochemical parameters of the groundwater of the Tista floodplain aquifer are calculated and shown in Table 3. From Table 3, it can be concluded that $\mathrm{pH}$ shows positive correlation only with $\mathrm{Ca}^{2+}$, whereas with other parameters like $\mathrm{Na}^{+}, \mathrm{K}^{+}, \mathrm{Ca}^{2+}$, $\mathrm{Mg}^{2+}, \mathrm{Fe}^{\text {Total }}, \mathrm{Cl}^{-}, \mathrm{HCO}_{3}{ }^{-}, \mathrm{SO}_{4}{ }^{2-}$ it show negative correlation with $\mathrm{pH}$. Here, the $\mathrm{EC}$ reflects the positive correlation with $\mathrm{Na}^{+}, \mathrm{K}^{+}, \mathrm{Mg}^{2+}, \mathrm{Fe}^{\text {Total }}, \mathrm{Cl}^{-}, \mathrm{HCO}_{3}{ }^{-}, \mathrm{SO}_{4}{ }^{2-}$. Moreover, $\mathrm{Na}-\mathrm{K}, \mathrm{Na}-\mathrm{Ca}, \mathrm{Na}-\mathrm{Mg}$ show the remarkable positive correlation pairs in the analysis. The $\mathrm{Cl}^{-}$, $\mathrm{HCO}_{3}{ }^{-}$and $\mathrm{SO}_{4}{ }^{2-}$ show positive correlations with the cations like $\mathrm{Na}^{+}, \mathrm{K}^{+}, \mathrm{Ca}^{2+}, \mathrm{Mg}^{2+}, \mathrm{Fe}^{\text {Total }}$.

\section{Hydrochemical facies in water of the Tista river active floodplain}

Piper trilinear diagram analysis The Piper trilinear diagram is one of the important tools that is used to interpret the hydrogeochemical facies (Piper 1944). The diagram shows the similarities and differences among water samples as those with similar qualities will have a tendency to fall in the same group (Todd 1980; Ramesh et al. 2014). Major cations $\left(\mathrm{Ca}^{2+}, \mathrm{Mg}^{2+}, \mathrm{Na}^{+}\right.$and $\left.\mathrm{K}^{+}\right)$and anions $\left(\mathrm{HCO}_{3}^{-}\right.$, $\mathrm{CO}_{3}{ }^{2-}, \mathrm{Cl}^{-}$and $\mathrm{SO}_{4}{ }^{2-}$ ) are plotted in the two basal triangles of the diagram, where all of the major cations and anions are expressed as percent of meq/L. The central portion of the diagram which is diamond shaped describes the classification of water. Among the major cations, $\mathrm{Na}^{+}$and $\mathrm{K}^{+}$are treated as alkalis and $\mathrm{Ca}^{2+}$ and $\mathrm{Mg}^{2+}$ are considered as alkaline earth. $\mathrm{HCO}_{3}{ }^{-}$and $\mathrm{CO}_{3}{ }^{2-}$ anions are designated as weak acid, while $\mathrm{Cl}^{-}$and $\mathrm{SO}_{4}{ }^{2-}$ ions are defined as strong acids. The hydrochemical facies of groundwater show that sodium, sodium-magnesium, sodium-calcium, sodium-magnesium-calcium and sodium-calcium-magnesium are cation facies and chloride-bicarbonate, bicarbonate-chloride and bicarbonate are anion facies (Fig. 4).

Potassium feldspar is resistant to chemical weathering, whereas sodic-feldspars and calcic-feldspars are susceptible to chemical changes. These minerals yield the metal cation and silica solution and commonly form clay minerals
Table 3 Correlation coefficient matrix of groundwater quality parameters $(n=19)$

\begin{tabular}{|c|c|c|c|c|c|c|c|c|c|c|}
\hline & $\mathrm{PH}$ & $\mathrm{EC}$ & $\mathrm{Na}^{+}$ & $\mathrm{K}^{+}$ & $\mathrm{Ca}^{2+}$ & $\mathrm{Mg}^{2+}$ & $\mathrm{Fe}$ & $\mathrm{Cl}^{-}$ & $\mathrm{HCO}_{3}^{-}$ & $\mathrm{SO}_{4}{ }^{2-}$ \\
\hline $\mathrm{pH}$ & 1.00 & & & & & & & & & \\
\hline EC & -0.24 & 1.00 & & & & & & & & \\
\hline $\mathrm{Na}^{+}$ & -0.37 & 0.75 & 1.00 & & & & & & & \\
\hline $\mathrm{K}^{+}$ & -0.21 & 0.47 & 0.52 & 1.00 & & & & & & \\
\hline $\mathrm{Ca}^{2+}$ & -0.10 & 0.54 & 0.63 & 0.61 & 1.00 & & & & & \\
\hline $\mathrm{Mg}^{2+}$ & -0.34 & 0.63 & 0.70 & 0.73 & 0.80 & 1.00 & & & & \\
\hline $\mathrm{Fe}$ & 0.17 & 0.14 & 0.21 & 0.19 & 0.29 & 0.17 & 1.00 & & & \\
\hline $\mathrm{Cl}^{-}$ & -0.43 & 0.53 & 0.75 & 0.62 & 0.39 & 0.54 & 0.24 & 1.00 & & \\
\hline $\mathrm{HCO}_{3}{ }^{-}$ & 0.01 & 0.64 & 0.73 & 0.60 & 0.52 & 0.57 & 0.40 & 0.56 & 1.00 & \\
\hline $\mathrm{SO}_{4}{ }^{2-}$ & -0.41 & 0.42 & 0.51 & 0.49 & 0.51 & 0.67 & - & 0.51 & 0.11 & 1.00 \\
\hline
\end{tabular}


with aluminum and part of the original silica (Hem 1989). Sodium may be presented as unaltered mineral grains in sediments that are resistant to weathering, as an impurity in cementing material, or as crystals of readily soluble sodium salts deposited within the sediments left in the sediments by saline seawater. Sodium ions are the most important cation in stream and spring water (Feth et al. 1964). High sodium concentration in water may be resulted from the mixing of freshwater with saline water bodies due to marine transgression during Holocene epoch in the Bengal Basin (Afroza et al. 2009).

Sources major ions in groundwater The Tista fan has developed by the sediments carried by the rivers, originating from the Himalayas, and draining through the Siwalik group of sediments (Rahman et al. 2013a, b). The chemistry of these sediments might have influence on the groundwater quality of the investigated area. Groundwater chemistry in the study area is regulated by different processes and mechanisms. The subtropical climatic conditions, rock-water interactions, precipitation and evaporation might have the significant role in groundwater chemistry. The Gibbs mechanisms (Gibbs 1970) were employed in the study, suggesting that groundwater chemistry in the investigated area has been influenced by the chemical weathering of rock-forming minerals existing in igneous rock, and ion exchange processes are the dominant solute acquisition mechanisms controlling the concentration of chemical constituents in groundwater and the anthropogenic sources also influence the groundwater composition (Apodaca et al. 2002; Martinez and Bocanegra 2002; Singh and Hasnain 2002; Jeelani and Shah 2006; Bhardwaj et al. 2010; Li et al. 2010; Jeelani et al. 2014).

From the observations, it is worthy to note that most of the major ions were high at shallow depth of the groundwater. The sources of the major ions in shallow groundwater may be resulted from the lithogenic and anthropogenic activities, mainly from agricultural activities. The lower concentration of major ions in greater depth of groundwater indicates that the sources of major ions are lithogenic in deeper aquifers and are naturally preserved from contamination by anthropogenic activities. The relative proportion of various dissolved ions in the groundwater depends on their abundance in the host rock/aquifer and their solubility (Sarin et al. 1989). The present research work has been carried out in the active portion of the floodplain deposits of the Tista River of Holocene age. The ion exchange between the groundwater and its host environment during the residence or during in movement
Fig. 4 Piper trilinear diagram of groundwater of the study area

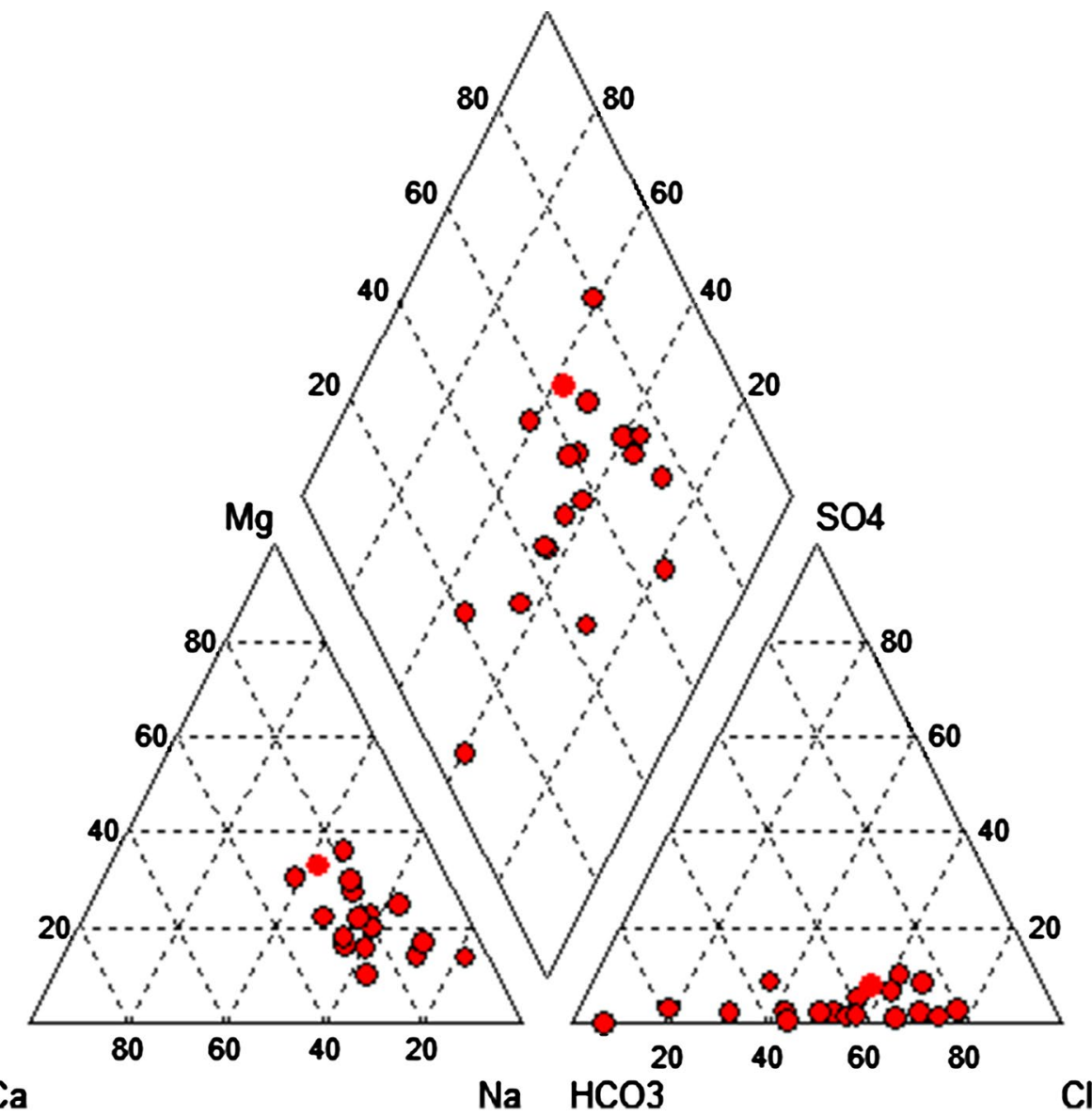


process can be best illustrated by chlorine alkaline indices which are also known as Schoeller index (Schoeller 1977). It is expressed as: $\mathrm{CAI}=\mathrm{Cl}^{-}-\left(\mathrm{Na}^{+}+\mathrm{K}^{+}\right) / \mathrm{Cl}^{-}$. A majority of the water samples from the groundwater $(58 \%)$ showed positive $\mathrm{CAI}$ indicating exchange of $\mathrm{Na}$ and $\mathrm{K}$ from the groundwater with $\mathrm{Mg}$ and $\mathrm{Ca}$ of the rocks, whereas $42 \%$ of the samples showed negative CAI indicating exchange of $\mathrm{Mg}$ and $\mathrm{Ca}$ of the water with $\mathrm{Na}$ and $\mathrm{K}$ of the rocks (Nagaraju et al. 2006). The $\mathrm{Cl}^{-} / \mathrm{HCO}_{3}{ }^{-}$values range from 0.068 to 3.911. Values of this hydrogeochemical index given for inland waters are between 0.1 and 5 (Nwankwoala and Udom 2011). The calculated values of the ratio of $\mathrm{Mg}^{2+} /$ $\left(\mathrm{Ca}^{2+}+\mathrm{Mg}^{2+}\right)$ of $84 \%$ of the groundwater samples are less than 0.5 indicating dolomite dissolution where the value of $16 \%$ of the groundwater samples is more than 0.5 indicating limestone-dolomite weathering.

Evaluation of water quality for irrigation Most natural waters are between $\mathrm{pH} 5$ and 8 . The generally accepted $\mathrm{pH}$ for irrigation water is in between 5.5 and 7.5.

Total hardness (TH) The total hardness (TH) is an important parameter of water for the utility of water in various purposes, for example domestic, industrial or agricultural purposes. The total hardness of water results from the excess concentration of $\mathrm{Ca}, \mathrm{Mg}$ and $\mathrm{Fe}$ salts in water. The average value of total hardness is $62.63 \mathrm{mg} / \mathrm{L}$ which reveals that 23\% water samples (Table 4) are soft in nature (Sawyer and McCarty 1967). The total hardness value of the water samples of the investigated area ranges from 20 to $160 \mathrm{mg} / \mathrm{L}$ which is less than the WHO recommended values $(500 \mathrm{mg} / \mathrm{L})$ for drinking water purposes (Islam et al. 2016).

Sodium adsorption ratio (SAR) The US Salinity Laboratory showed that the sodium adsorption ratio (SAR) reasonably estimates the degree to which irrigation water tends to enter into cation-exchange reaction in soil. High magnitudes of SAR imply a hazard of sodium replacing absorbed calcium and magnesium, and lead to a condition that ultimately damages the soil structure (Khan and Abbasi 2013).

The median value of SAR is 2.12 which denotes that the studied water samples are excellent in quality for irrigation. The SAR value of the water samples of the investigated area ranges from 0.79 to 5.53 as shown in Table 4 . The SAR value of all this samples indicates the excellent quality for irrigation water.

Residual sodium carbonate (RSC) The concentration of bicarbonate and carbonate controls the suitability of water for irrigation (Reddy 2013). One of the empirical approaches was made based on the assumption of the precipitation of calcium and magnesium carbonates considering the hypothesis Eaton, 1950 proposed by the concept of residual sodium carbonate (RSC) for the measurement of high carbonate
Table 4 Showing the values of irrigation parameters of groundwater of the study area

\begin{tabular}{|c|c|c|c|c|c|c|}
\hline Location & $\mathrm{TH}(\mathrm{mg} / \mathrm{L})$ & RSC (meq/L) & PI $(\%)$ & SAR & SSP $(\%)$ & MH (\%) \\
\hline SBN & 100.00 & 0.50 & 90.48 & 2.40 & 57.36 & 40.00 \\
\hline DKN & 40.00 & 0.35 & 115.11 & 1.58 & 56.99 & 50.00 \\
\hline DBN & 110.00 & 0.15 & 87.17 & 2.86 & 60.00 & 54.55 \\
\hline BHL & 70.00 & 0.15 & 93.53 & 1.20 & 50.88 & 57.14 \\
\hline BKL & 40.00 & 0.05 & 109.35 & 0.79 & 42.45 & 50.00 \\
\hline JBN & 70.00 & 0.35 & 97.96 & 2.87 & 63.82 & 28.57 \\
\hline MGR & 20.00 & 0.50 & 139.19 & 2.24 & 72.03 & 50.00 \\
\hline HBR & 40.00 & 2.20 & 121.68 & 5.53 & 82.83 & 75.00 \\
\hline DCR & 40.00 & -0.15 & 100.44 & 0.79 & 45.21 & 50.00 \\
\hline KBR & 70.00 & 0.25 & 96.01 & 1.79 & 53.95 & 57.14 \\
\hline SPL & 30.00 & 1.10 & 163.99 & 0.91 & 46.43 & 66.67 \\
\hline TBL & 160.00 & -0.95 & 72.58 & 2.37 & 52.94 & 43.75 \\
\hline PCR & 50.00 & 0.10 & 101.39 & 3.54 & 72.14 & 60.00 \\
\hline SPR & 20.00 & 0.65 & 169.37 & 1.12 & 59.18 & 50.00 \\
\hline DWG & 120.00 & -0.80 & 80.76 & 3.20 & 60.46 & 50.00 \\
\hline RGG & 30.00 & 0.05 & 112.86 & 1.83 & 63.19 & 66.67 \\
\hline RBK & 50.00 & 0.55 & 112.23 & 1.41 & 51.46 & 60.00 \\
\hline BUK & 80.00 & 0.50 & 95.81 & 2.24 & 56.87 & 37.50 \\
\hline RCK & 50.00 & 0.40 & 107.33 & 2.12 & 60.94 & 40.00 \\
\hline Average & 62.63 & 0.31 & 108.80 & 2.15 & 58.37 & 51.95 \\
\hline \multirow[t]{4}{*}{ Median } & 50.00 & 0.35 & 101.39 & 2.12 & 57.36 & 50.00 \\
\hline & Soft $23 \%$ & Safe $100 \%$ & - & Excellent $100 \%$ & - & Safe $58 \%$ \\
\hline & Mod. Hard $61.5 \%$ & - & - & - & - & - \\
\hline & Hard $15.5 \%$ & - & - & - & - & - \\
\hline
\end{tabular}


Table 5 Upper limit of TDS for livestock consumption

\begin{tabular}{lccl}
\hline Livestock & $\begin{array}{l}\text { Upper limit of } \\
\text { TDS }(\mathrm{mg} / \mathrm{L})\end{array}$ & Limit of TDS in the study area $(\mathrm{mg} / \mathrm{L})$ & Comments \\
\hline Poultry & 2860 & $73.7-797.3$ & Within the allowable limit and suitable for livestock consumption \\
Pigs & 4290 & & \\
Horses & 6435 & \\
Dairy cattle & 7150 & \\
Beef cattle & 10,000 & \\
Lambs & 12,900 & \\
\hline
\end{tabular}

waters. Residual sodium carbonate (RSC) determines the hazardous effects of carbonate and bicarbonate on the quality of water for agricultural purpose.

The average value of residual sodium carbonate is $0.31 \mathrm{meq} / \mathrm{L}$. According to US Salinity Laboratory 1954 , the magnitude of all the water samples was less than $1.25 \mathrm{meq} / \mathrm{L}$, which is an indicative of safe water quality for irrigation.

Permeability index $(P I)$ The permeability of soil is influenced by the continuous use of irrigation water. By the amounts of sodium, calcium, magnesium and bicarbonate ions, the soil is increased by the utility of irrigation water (Chandu et al. 1995). The permeability index (PI) is a measure suitability of water for irrigation purpose. The permeability index (PI) is categorized as class I (>75\%), class II $(25-75 \%)$ and class III $(<25 \%)$. The waters under class I and class II are designated as good for irrigation that have PI 25\% and above, while class III waters have PI values less than 25\% and unsuitable for irrigation (Doneen 1964; WHO 1989). The permeability index of the groundwater of the investigated wells is $72 \%$ and above, whereas they fall in class I and class II, which are suitable for irrigation purposes.

Soluble sodium percent (SSP) The soluble sodium percent is a measure of the tendency for a water to enter into cationexchange reactions (Khan and Abbasi 2013). It is the percent of total cations made up by $\mathrm{Na}$ ions. The divalent cations normally occupy the exchangeable positions on clay minerals, the extensive displacement of calcium and magnesium ions by $\mathrm{Na}$ ions unless the SSP is considerably higher than $50 \%$ of the total concentration of the solutes is large (Hem 1989). Soluble sodium percent (SSP) is an important factor for the classification of irrigation water. A certain ratio of air water in the pore spaces of the soil is essential for the proper nutrition and growth of the plants. The watercontaining sodium reacts with the soil, accumulates in the void spaces the soil and reduces the permeability of the soil. The sodium concentration is expressed in terms of soluble sodium percent. The maximum permissible limit of SSP is $60 \%$ for irrigation water. Sixty-eight percent of the studied water samples have the SSP value less than $60 \%$.
Magnesium hazard (MH) Magnesium and calcium ions are essential for plant growth although these ions may be added with the soil aggregation and cause friability of soil. High concentration of calcium and magnesium of irrigation water can increase the $\mathrm{pH}$ of soil that may cause loss of phosphorus. Magnesium ions are also important for the productivity of soil. The water is safe and suitable for irrigation if the numerical value of magnesium hazard $(\mathrm{MH})$ is less than 50\% (Szabolcs and Darab 1964). The value of 58\% of the water samples of the study area less than $50 \%$ is safe and suitable for irrigation purposes.

\section{Assessment of water quality for livestock}

Water is essential for all forms of life. The availability of adequate quantity and quality of water has the largest impact of types of life and number of individuals that an environment can sustain and may be a limiting factor for livestock production systems. Water is an essential second only to oxygen in importance to sustain life and optimum growth, lactation and reproduction of dairy cattle (Breede 2006). Water is a medium for transportation of nutrients, waste products, hormones and other electrolytes, and aids in the movement of food through the gastrointestinal tract (Lardner et al. 2005). For the livestock, high-quality water should be provided in order to prevent them from different diseases, salt imbalance and poisoning from toxic components (Bhardwaj and Singh 2011). Most of the water quality variables for livestock are same as for human drinking water, although the total permissible levels of total suspended solids and salinity may be higher (Bhardwaj and Singh 2011). The total dissolved solids (TDS) are the main parameter usually used to assess the suitability of any water for livestock farming. Based on the Australian and UNESCO standards, the TDS value between 0 and $2900 \mathrm{mg} / \mathrm{L}$ is suitable for all the animals (Hamill and Bell 1986; Jeelani et al. 2014). In this case, the groundwater is good for livestock purposes as the TDS in groundwater ranged from 73.7 to $797.3 \mathrm{mg} / \mathrm{L}$ (Table 5). 


\section{Conclusion}

The study reveals that the environment sensitive index parameters like $\mathrm{pH}, \mathrm{EC}$ and the temperature values of the groundwater samples in the study area are within the permissible limit. The mean concentration of major cations in the groundwater samples is $\mathrm{Na}^{+}>\mathrm{Ca}^{+2}>\mathrm{Mg}^{+2}>\mathrm{K}^{+}$, whereas the major anions is $\mathrm{HCO}_{3}{ }^{-}>\mathrm{Cl}^{-}>\mathrm{SO}_{4}^{-2}$. Among the cations, $\mathrm{Na}^{+}$is the dominant and $\mathrm{K}^{+}$is the lowest constituents, whereas $\mathrm{HCO}_{3}{ }^{-}$is most abundant and $\mathrm{SO}_{4}^{-2}$ is the minor constituents in anions. Concentrations of calcium, magnesium and sodium of all the samples are within the permissible limit. Correlating with WHO (1997) and EQS (1989) guideline values for drinking water and public health, it may be concluded that the groundwater of the study area is suitable for all drinking and domestic purposes, where only three samples exceed the maximum allowable limit of potassium. The allowable concentrations of all chemical parameters suggest that the quality of the groundwater is mainly controlled by geogenic processes. The excess concentration of potassium in three groundwater samples might be resulted from anthropogenic activities like use of fertilizer. Based on total hardness, SAR, RSC, PI, SSP and MH values, it can be summarized that the groundwater of the investigated area has excellent quality for irrigation purpose. On the basis of Australian and UNESCO standard, the groundwater of the study area is also suitable for livestock purposes. Further research works can be taken to show the seasonal variation of the geochemical parameters of the groundwater in the investigated area.

Acknowledgements The authors are grateful to Soil Resource Development Institute (SRDI), Dhaka, for providing kind permission to analyze the groundwater samples in the Laboratory of SRDI. The authors convey due thanks to Professor Dr. Golam Sabbir Sattar, Ex-Chairman and Professor Dr. Khondaker Emamul Haque, Chairman Department of Geology and Mining, University of Rajshahi, Bangladesh, for arranging the research work. Finally, the authors are very thankful to Dr. Enrico Drioli, Editor-in-chief for his kind co-operation regarding the review process, advice and publication of this research.

Open Access This article is distributed under the terms of the Creative Commons Attribution 4.0 International License (http://creativeco mmons.org/licenses/by/4.0/), which permits unrestricted use, distribution, and reproduction in any medium, provided you give appropriate credit to the original author(s) and the source, provide a link to the Creative Commons license, and indicate if changes were made.

\section{References}

Afroza R, Mazumder QH, Jahan CS, Kazi MAI, Ahsan MA, Al-Mansur MA (2009) Hydrochemistry and origin of salinity in groundwater in parts of lower Tista floodplain, Northwest Bangladesh. J Geol Soc India 74:223-232
American Public Health Association (APHA) (1995) Standard methods for the examination of water and wastewater, 16th edn. American Public Health Association, Washington

Anderson F (2014) Multivariate geostatistical model for groundwater constituents in Texas. Int J Geosci 5:1609-1617. https://doi. org/10.4236/ijg.2014.513132

Apodaca LE, Jeffrey BB, Michelle CS (2002) Water quality in shallow alluvial aquifers, Upper Colorado River Basin. J Am Water Res 38(1):133-143

Bahar MM, Reza MS (2010) Hydrochemical characteristics and quality assessment of shallow groundwater in a coastal area of southwest Bangladesh. Environ Earth Sci 61:1065-1073. https://doi. org/10.1007/s12665-009-0427-4

Bhardwaj V, Singh DS (2011) Surface and groundwater quality characterization of Deoria district, Ganga plain, India. Environ Earth Sci 63:383-395. https://doi.org/10.1007/s12665-010-0709-x

Bhardwaj V, Singh DS, Singh AK (2010) Hydrochemistry of groundwater and anthropogenic control over dolomitization reactions on alluvial sediments of the Deoria district-Ganga plain, India. Environ Earth Sci 59:1099-1109. https://doi.org/10.1007/s1266 5-009-0100-y

Bhattacharyya D, Mukherjee PK (2009) Contamination of shallow aquifers by arsenic in upper reaches of Tista river at Siliguri-Jalpaiguri area of West Bengal, India. Environ Geol 57(7):1687-1692

Breede DK (2006) Evaluation of water quality and nutrition for dairy cattle. In: High Plains Dairy conference

Chandu SN, Sibbarao NV, Prakash SR (1995) Suitability of groundwater for domestic and irrigational purposes in some parts of Jhansi District, U.P. Bhujal News 10(1):12-17

Doneen LD (1964) Water quality for agriculture. Department of Irrigation, University of California, California, $\mathrm{p} 48$

Eaton FM (1950) Significance of carbonate in irrigation water. Soil Sci 67:112-133

EQS (1989) Environmental quality standard. Department of Environment, Bangladesh

Feth JH, Roberson CE, Polzer WL (1964) Sources of mineral constituents in water from granitic rocks, Sierra Nevada, California and Nevada, U.S. Geological survey water-supply paper, 1535-L, p 70

Ganyaglo SY, Benoeng-Yakubo B, Osae S, Dampare SB, Fianko JR, Bhuiyan MAH (2010) Hydrochemical and isotopic characterisation of groundwaters in the eastern region of Ghana. J Water Resour Prot 2:199-208

Gastmans D, Chang HK, Hutcheon I (2010) Groundwater geochemical evolution in the northern portion of the guarani aquifer system (Brazil) and its relationship to diagenetic features. Appl Geochem 25:16-33

Gibbs RJ (1970) Mechanisms controlling world water chemistry. Science 170:795-840

Hamill L, Bell FG (1986) Groundwater resource development and management. The University Press, Cambridge, p 34

Haque KE (2009) Geochemical assessment of groundwater in the foothills area of Siliguri, Darjeeling District, India. Int J Earth Sci Eng 2(2):135-144

Hem JD (1989) Study and interpretation of the chemical characteristics of natural water, vol 2254, 3rd edn. USGS WSP, Washington D.C., pp 1-263

Howlader MF, Deb PK, Mazumder ATMSH, Ahmed M (2014) Evaluation of water resources around Barapukuria coal mine industrial area, Dinajpur, Bangladesh. Appl Water Sci 4:203-222. https:// doi.org/10.1007/s13201-014-0207-5

Hussain MM, Abdullah SKM (2001) Geological setting of the areas of arsenic aquifers, ground water task force, interim report no.1, Local Government Division, Ministry of Local Government, Rural Development \& Cooperatives, Bangladesh, pp A 1-A 45. http://fineprint.com. Accessed 3 July 2013

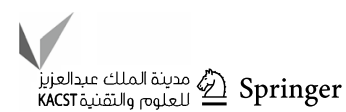


Islam MR, Sarkar MKI, Afrin T, Rahman SS, Talukder RI, Howlader BK, Khaleque MA (2016) A study on total dissolved solids and hardness level of drinking mineral water in Bangladesh. Am J Appl Chem 4(5):164-169. https://doi.org/10.11648/j.ajac.20160 405.11

Islam ARMT, Shen S, Bodrud-Doza M, Rahman MA, Das S (2017) Assessment of trace elements of groundwater and their spatial distribution in Rangpur district, Bangladesh. Arab J Geosci 10:95. https://doi.org/10.1007/s12517-017-2886-3

Jeelani GH, Shah AQ (2006) Geochemical characteristics of water and sediment from the Dal Lake, Kashmir Himalaya, India: constraints on weathering and anthropogenic activity. Environ Geol 50:12-23

Jeelani GH, Shah RA, Hussain A (2014) Hydrogeochemical assessment of groundwater in Kashmir Valley, India. J Earth Syst Sci 123(5):1031-1043

Khan TA, Abbasi MA (2013) Synthesis of parameters used to check the suitability of water for irrigation purposes. Int J Environ Sci 3(6):2031-2038. https://doi.org/10.6088/ijes.2013030600029

Khan D, Hagras MA, Iqbal N (2014) Groundwater quality evaluation in Thal Doab of Indus Basin of Pakistan. Int J Modern Eng Res 4(1):36-47

Khashogji MS, El Maghraby MMS (2013) Evaluation of groundwater resources for drinking and agricultural purposes, Abar Al Mashi area, south Al Madinah Al Munawarah City, Saudi Arabia. Arab J Geosci 6(10):3929-3942. https://doi.org/10.1007/s1251 7-012-0649-8

Kirk MF, Holm TR, Park J, Jin Q, Sanford RA, Fouke BW, Bethke CM (2004) Bacterial sulfate reduction limits natural arsenic contamination in groundwater. J Geol 32(11):953-956

Lardner HA, Kirychuk BD, Braul L, Williams WD, Yarotski J (2005) The effect of water quality on cattle performance on pasture. Aust J Agric Res 56:97-104

Li PY, Qian H, Wu JH, Ding J (2010) Hydrochemical formation mechanisms and quality assessment of groundwater with improved TOPSIS, method in Pengyang County, northwest China. J Chem 8(3):1164-1173

Martinez DE, Bocanegra EM (2002) Hydrogeochemistry and cation exchange processes in the coastal aquifer of Mar Del Plata, Argentina. Hydrogeol J 10:393-408

Matthess G (1982) The properties of groundwater. Wiley, New York, p 397p

Mazumder QH, Jahan CS, Roy MK (1994) Sphericity and roundness study of the Tista River clastics, Rangpur, Bangladesh. Rajshahi Univ Stud Part B 22:141-152

Meetei LI, Pattanayak SK, Bhaskar A, Pandit MK, Tandon SK (2007) Climatic inprints in Quaternary valley fill deposits of the middle Teesta valley, Sikkim Himalaya. Quaternary Int 159(1):32-46

Mostafa MG, Uddin SMH, Haque ABMH (2017) Assessment of hydrogeochemistry and groundwater quality of Rajshahi City in Bangladesh. Appl Water Sci. https://doi.org/10.1007/s13201-017-0629-y

Nag SK (2009) Quality of groundwater in parts of ARSA block, Purulia District, West Bengal. Bhu-Jal 4(1):58-64

Nagaraju A, Suresh K, Killham K, Hudson-Edwards K (2006) Hydrogeochemistry of waters of Mangampete barite mining area Cuddapah Basin, Andhra Pradesh, India. Turk J Eng Environ Sci 30:203-219

Nwankwoala HO, Udom GJ (2011) Hydrochemical facies and ionic ratios of groundwater in Port Harcourt, Southern Nigeria. Res J Chem Sci 1(3):87-101

Piper AM (1944) A graphic procedure in the geochemical interpretations of water analyses. Trans Am Geophys Union 25:914-923

Raghunath HM (1987) Groundwater, 2nd edn. Wiley Eastern Ltd., Hoboken, pp 344-563

Rahman MA, Alam MJ, Siddique NEA, Alam AMS (2013a) Distribution of arsenic with iron, manganese and copper in borehole sediments of the Tista and Jamuna. Int Dhaka Univ J Sci 61(2):207-210

$\sqrt{10}$

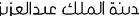

KACST
Rahman MM, Reza AHMS, Rahman MM, Islam R, Rahman MA (2013b) Geochemical characterization of groundwater in Bhangamor Union, Fulbari Upazila, Kurigram. Int J Chem Mater Sci 1(2):022-035

Ramesh K, Nithya K, Vennila S (2014) Groundwater quality assessment of Kurunthancode block in Kanya kumari District, India. Int J ChemTech Res 6:4585-4594

Reddy KS (2013) Assessment of groundwater quality for irrigation of Bhaskar Rao Kunta watershed, Nalgonda District, India. Int J Water Resour Environ Eng 5(7):418-425. https://doi.org/10.5897/ IJWREE2012.0375

Richards LA (1954) Diagnosis and improvement of saline and alkaline soils. U.S Department of Agriculture Hand Book, Washington, p 60p

Robins NS (2002) Groundwater quality in Scotland: major ion chemistry of the key groundwater bodies. Sci Total Environ 294:41-56

Sarin MM, Krishnaswamy S, Dilli K, Somayajulu BLK, Moore WS (1989) Major ion chemistry of the Ganga-Brahmaputra river system: weathering processes and fluxes to the Bay of Bengal. Geochim Cosmochim Acta 53:997-1009

Sawyer GN, McCarty DL (1967) Chemistry of sanitary engineers, 2nd edn. Mcgraw Hill, New York, p 518

Sawyer GN, McMcartly DL, Parkin GF (2003) Chemistry for environmental engineering and science, 5th edn. Mcgraw Hill, New York, $\mathrm{p} 152$

Schoeller H (1977) Geochemistry of groundwater. In: Groundwater studies, an international guide for research and practice, UNESCO, Paris, Chapter 15, pp 1-18

Selvam S, Manimaran G, Sivasubramanian P (2013) Hydrochemical characteristics and GIS-based assessment of groundwater quality in the coastal aquifers of Tuticorin corporation, Tamilnadu, India. Appl Water Sci 3:145-159

Singh AK, Hasnain SJ (2002) Aspects of weathering and solute acquisition processes controlling the chemistry of sub-alpine proglacial streams of Garhwal Himalaya, India. Hydrol Process 16:835-849

Srivastava SK, Ramanathan AL (2008) Geochemical assessment of groundwater quality in vicinity of Bhalswa landfill, Delhi, India using graphical and multivariate statistical methods. Environ Geol 53:1509-1528

Sultana S (2009) Hydrogeochemistry of the Lower Dupi Tila Aquifer in Dhaka City, Bangladesh. TRITA-LWR degree project 09-35, pp 1-42

Szabolcs I, Darab C (1964) The influence of irrigation water of high sodium carbonate content of soil. In: Proceedings of 8th international congress issue transactions vol 2, pp 803-812

Todd DK (1980) Groundwater hydrology, 2nd edn. Wiley, New York, $\mathrm{p} 70$

UNDP (United Nations Development Programme) (1982) Groundwater survey: the hydrogeological conditions of Bangladesh. UNDP technical report DP/UN/BGD-74-009/1

US Salinity Laboratory Staff (1954) Diagnosis and improvement of saline and alkalis soil, vol 60. US Department of Agriculture Handbook, Washington, D.C., p 160

WHO (1989) Health guidelines for the use of wastewater in agriculture and aquaculture. In: Report of a WHO scientific group: technical report series, World Health Organisation, Geneva, p 778

WHO (1997) Guidelines for drinking-water quality, 1. World Health Organisation, Geneva

Wiejaczka L, Bucala A, Sarkar S (2014) Human role in shaping the hydromorphology of the Himalayan rivers: study of the Tista River in Darjeeling Himalaya. Curr Sci 106(5):717-724

Publisher's Note Springer Nature remains neutral with regard to jurisdictional claims in published maps and institutional affiliations. 